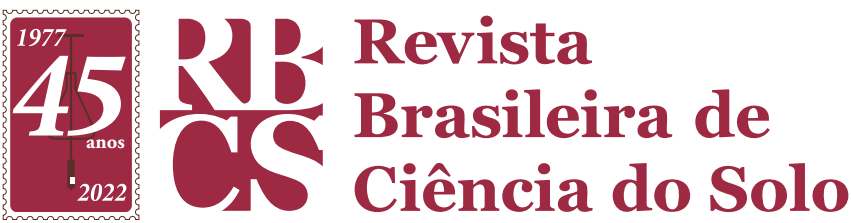

Division - Soil Use and Management | Commission - Soil and Water Management and Conservation

\title{
Cover crops and controlled-release urea decrease nitrogen mobility and improve nitrogen stock in a tropical sandy soil with cotton cultivation
}

\author{
Carlos Felipe dos Santos Cordeiro ${ }^{(1) *}\left(\mathbb{D}\right.$, Daniel Rodela Rodrigues ${ }^{(2)}(\mathbb{D}$, Ana Flávia de \\ Souza Rorato ${ }^{(3)}$ (D) and Fábio Rafael Echer $^{(4)}$ (iD \\ (1) Universidade Estadual Paulista "Júlio de Mesquita Filho", Faculdade de Ciências Agronômicas, \\ Departamento de Produção Vegetal, Programa de Pós-Graduação em Agricultura, Botucatu, São Paulo, \\ Brasil. \\ (2) Universidade do Oeste Paulista, Departamento de Agronomia, Programa de Pós-Graduação em Produção \\ Vegetal, Presidente Prudente, São Paulo, Brasil. \\ (3) Universidade do Oeste Paulista, Departamento de Agronomia, Graduação em Agronomia, Presidente \\ Prudente, São Paulo, Brasil. \\ (4) Universidade do Oeste Paulista, Departamento de Agronomia, Presidente Prudente, São Paulo, Brasil.
}

* Corresponding author:

E-mail: cordeirocfs@gmail.com

Received: August 10, 2021

Approved: November 16, 2021

How to cite: Cordeiro CFS, Rodrigues DR, Rorato AFS, Echer FR. Cover crops and controlled-release urea decrease nitrogen mobility and improve nitrogen stock in a tropical sandy soil with cotton cultivation. Rev Bras Cienc Solo. 2022;46:e0210113.

https://doi.org/10.36783/18069657rbcs20210113

Editors: José Miguel Reichert (DD and Tales Tiecher (1).

Copyright: This is an open-access article distributed under the terms of the Creative Commons Attribution License, which permits unrestricted use, distribution, and reproduction in any medium, provided that the original author and source are credited.
ABSTRACT: Sandy soil often has low nitrogen (N) stock. Thus, crops grown in sandy soil rely on high levels of $\mathrm{N}$ fertilization. The use of cover crops and efficient fertilizers can increase $\mathrm{N}$ stock in the soil and $\mathrm{N}$ availability in the topsoil, and reduce overall fertilizer costs. The objective of this study was to evaluate the effects of cover crops (fallow, a single grass species (ruzigrass), two grass species (ruzigrass + millet), one grass species (millet) with legumes [lime-yellow pea (2018) and velvet bean (2019)], and a mixture of three cover crops [two grass species (ruzigrass + millet) and one legume (lime-yellow pea (2018)] and velvet bean (2019), $\mathrm{N}$ sources (conventional urea and controlled-release urea) and $\mathrm{N}$ doses $\left(70,100\right.$ and $130 \mathrm{~kg} \mathrm{ha}^{-1}$ ) on $\mathrm{N}$ dynamics in an Oxisol (Latossolo) with sandy texture in Brazil cultivated with cotton. Systems with the cover crops (average) had $17 \%$ more total $\mathrm{N}$ stock in the soil than fallow systems. Inorganic $\mathrm{N}$ increased only in systems with legumes. The systems with cover crop mixtures had $70 \%$ more ammonium than fallow systems. Systems only with grass species had low percentages of inorganic $\mathrm{N}$ in relation to total $\mathrm{N}$ in the soil. The increase in $\mathrm{N}$-fertilizer rates augmented the $\mathrm{N}$ stock in the soil (total and inorganic). In the first year, controlled-release urea reduced the availability of inorganic $\mathrm{N}$ in cotton flowering, except for the system with mixed cover crops. After the cotton harvest, areas of controlled-release urea application had $12 \%$ more inorganic $\mathrm{N}$ than the areas with conventional urea. Our findings show that the combined use of cover crops with high biomass production, moderate dose of $\mathrm{N}$ and controlled-release $\mathrm{N}$ can increase the availability of inorganic nitrogen in the upper layers of the soil in tropical areas with sandy soil and this can reduce nitrogen fertilizer consumption in the medium and long term in cotton fields.

Keywords: crop rotation, nitrogen sources, nitrogen mobility, Oxisols. 


\section{INTRODUCTION}

Nitrogen ( $\mathrm{N}$ ) dynamics in tropical soils are complex, as $\mathrm{N}$ loss is often caused by volatilization (Minato et al., 2020) and leaching (Rosolem et al., 2018). Leaching nitrate runoff and denitrification remove up to 95 and $25 \mathrm{Tg}$ of nitrate from the soil each year, respectively. Ammonium volatilization removes up to $37 \mathrm{Tg}$ of ammonium from the soil each year (Billen et al., 2013; Sutton et al., 2013). In sandy soil, the risk of losses from leaching is high due to low cation exchange capacity (CEC) and low soil organic matter content. These factors reduce the soil capacity to store $\mathrm{N}$, as well as increase the need for mineral fertilizers, mainly in non-leguminous crops (Shareef et al., 2019), as for example in cotton crops, which require application of $\mathrm{N}$ via nitrogen fertilizer. New techniques are needed to improve $\mathrm{N}$ efficiency in tropical climates and sandy soil regions.

Use of cover crops is a common technique to improve $\mathrm{N}$ efficiency, and its use has shown benefits for various crop systems (Rosolem et al., 2018; Momesso et al., 2019; Rocha et al., 2019; Rocha et al., 2020; Galdos et al., 2020). In some cases, the use of grass with a high carbon-to-nitrogen ratio ( $\mathrm{C}: \mathrm{N}$ ) causes $\mathrm{N}$ immobilization due to the use of $\mathrm{N}$ available in the soil by microorganisms, which decompose the straw; this momentarily reduces the availability of $\mathrm{N}$ in the subsequent crop (Momesso et al., 2019; Rocha et al., 2019; Silva et al., 2020). The low organic matter content in sandy soil results in low $\mathrm{N}$ stock (Cordeiro and Echer, 2019; Silva et al., 2020; Cordeiro et al., 2021a). When choosing the cover crop species in these soils, it is important to consider which crop will be grown in the future, as non-legume crops (e.g., cotton) depend on fertilizers and soil $\mathrm{N}$ reserve. When compared to using just grass, Chu et al. (2017) and Silva et al. (2020) reported higher $\mathrm{N}$ stock and higher soybean and corn yields when using grass and legume cover crop combinations. However, these studies did not evaluate the effect of cover crops on $\mathrm{N}$ loss or ammonium and nitrate proportions. This is important because the nitrate fraction is more easily lost in sandy soils, while ammonium can be deposited in the soil CEC (Teutscherova et al., 2018).

Legumes have the capacity to increse $\mathrm{N}$ content in the soil via biological nitrogen fixation (BNF) (Cordeiro and Echer, 2019; Cordeiro et al., 2021a). Legumes grown in the off-season increases $\mathrm{N}$ absorption and yield of subsequent crops, reducing the necessity for mineral fertilization (Silva et al., 2006). Nitrogen loss from leaching is higher in legume systems than in grass systems, as systems with legumes have lower $\mathrm{C}: \mathrm{N}$ ratios. Low $\mathrm{C}: \mathrm{N}$ ratios accelerate $\mathrm{N}$ release, decrease root volumes and increase $\mathrm{N}$ input in the soil (Rosolem et al., 2017).

Systems with grass have high $\mathrm{C}: \mathrm{N}$ ratios and nutrient cycling capabilities (principally with nitrates); these factors enhance the soil by enabling large root development (Rosolem et al., 2017) and inhibiting N nitrification (Subbarao et al., 2007; Subbarao et al., 2009). The combination of grass and legumes in the off-season can improve nutrient cycling, increase $\mathrm{N}$ stock in the soil, and reduce loss from leaching and nitrification. However, the use of cover crops from different botanical families in the same crop system is not a common practice in tropical climates. Furthermore, there is still no knowledge of cover crops on the dynamics of $\mathrm{N}$ in the soil in cotton-growing areas on sandy soils.

Adjustments to $\mathrm{N}$ doses are also necessary for these systems, principally for cotton cultivation. Cotton crops require high amounts of mineral fertilizer and are usually grown in areas with high rainfall or irrigation systems. These factors facilitate $\mathrm{N}$ movement in the soil. Leaching does not cause significant $\mathrm{N}$ loss in applications of less than $100 \mathrm{~kg} \mathrm{ha}^{-1}$ of $\mathrm{N}$, but leaching can cause significant $\mathrm{N}$ loss (up to $10 \%$ ) when high $\mathrm{N}$ doses are used (300 kg ha ${ }^{-1}$ or more) (Wang et al., 2019). This is a problem for cotton cultivation in various countries. In Brazil, average N application is between 100 to $200 \mathrm{~kg} \mathrm{ha}^{-1}$ (Echer et al., 2020). Average $\mathrm{N}$ application in the United States is around $200 \mathrm{~kg} \mathrm{ha}^{-1}$ (Bronson et al., 2019). In China and Australia, $\mathrm{N}$ application is often around $300 \mathrm{~kg} \mathrm{ha}^{-1}$ (Tian et al., 2018; Rochester and Constable, 2020). 
Use of controlled-release fertilizers is a strategy to reduce the applied $\mathrm{N}$ dose (Yang et al., 2021), but despite the high efficiency of controlled-release urea (CRU), its use is not common in Brazil and various other countries. Recent studies have suggested that CRU application results in a $9 \%$ increase in cotton yield (Geng et al., 2016a) and $36 \%$ less volatilization loss (Minato et al., 2020). Elemental sulfur-coated urea is a good option for tropical climate environments (Mariano et al., 2019). Applying CRU reduces the amount of the required $\mathrm{N}$ dose by up to $50 \%$. It also reduces inorganic $\mathrm{N}$ leaching (Zhang et al., 2018).

However, it is unclear if CRU efficiency is dependent on the crop production system, and coating technology. In addition, the effects from the combination of CRU coated with elemental sulfur and polymers and cover crop systems on soil $\mathrm{N}$ stock and leaching in tropical regions with sandy soil are not yet fully understood. The objective of this study was to evaluate the interactive effects of cover crops, $\mathrm{N}$ sources, and $\mathrm{N}$ doses on $\mathrm{N}$ stock and $\mathrm{N}$ movement in tropical sandy soil with cotton cultivation.

\section{MATERIALS AND METHODS}

\section{Characterization of the study area}

The present study was conducted in the 2018/2019 and 2019/2020 crop seasons in the of Presidente Bernardes, São Paulo State, Brazil (22 $11^{\prime} 53^{\prime \prime} \mathrm{S}, 51^{\circ} 40^{\prime} 30^{\prime \prime}$ W, at an altitude of $401 \mathrm{~m}$ ). The region has a tropical climate with dry winters (Aw Köppen Classification System). Rainfall amounts during the cover crop cycles were 292 and $242 \mathrm{~mm}$ in 2018/2019 and 2019/2020, respectively. Rainfall amounts during the cotton cycles were $642 \mathrm{~mm}$ in 2018/2019 and $944 \mathrm{~mm}$ in 2019/2020. The soil of the area is classified as Oxisols (Soil Survey Staff, 2014), which corresponds to a Latossolo (Santos et al., 2013), with a sandy texture ( $14 \%$ clay, 0.00-0.20 m). Before implementation of crop rotation systems, we recorded the following chemical properties $(0.00-0.20 \mathrm{~m})$ (2015): pH: 5.0, organic carbon: $8.9 \mathrm{~g} \mathrm{dm}^{-3}$, total nitrogen: $210 \mathrm{mg} \mathrm{kg}^{-1}$, inorganic nitrogen: $12 \mathrm{mg} \mathrm{kg}^{-1}$, phosphorus: $2.1 \mathrm{mg} \mathrm{dm}^{-3}$, potassium, calcium, magnesium, and CEC of 0.6 , 7.5, 3.8, and $27.5 \mathrm{mmol}_{\mathrm{c}} \mathrm{dm}^{-3}$, respectively. At layers of $0.00-0.20,0.20-0.40,0.40-0.60$, 0.60-0.80 and $0.80-1.00 \mathrm{~m}$, we recorded the following physical properties: clay contents of 143,146,174, 191 and $184 \mathrm{~g} \mathrm{~kg}^{-1}$; sand contents of 835, 815, 779, 778 and $776 \mathrm{~g}$ $\mathrm{kg}^{-1}$; and silt contents of $22,39,47,31$ and $40 \mathrm{~g} \mathrm{~kg}^{-1}$, respectively. Crop rotation systems were implemented in 2015.

\section{Experimental design}

Randomized blocks with five replications were used in a split-split plot scheme for the experimental design. Plots were composed of the following rotation systems: fallow (spontaneous vegetation), a single grass species (SG), two grass species $(\mathrm{G}+\mathrm{G})$, one grass species and legumes $(\mathrm{G}+\mathrm{L}$ ), and a mixture of three cover crops (two grass species and one legume) (MIX). Subplots were divided by nitrogen (N) doses: 70, 100 and $130 \mathrm{~kg} \mathrm{ha}^{-1}$. Sub-subplots were divided by $\mathrm{N}$ sources: conventional urea $(45 \% \mathrm{~N})$ and controlled-release urea (CRU). Controlled-release urea was coated with elemental sulfur ( $40 \% \mathrm{~N}+8 \% \mathrm{~S})$. Nitrogen fertilizers were applied 25 and 45 days after cotton emergence. Plots had dimensions of $15 \times 9 \mathrm{~m}$. Subplots had dimensions of $4.5 \times 9 \mathrm{~m}$. Sub-subplots were then divided into $4.5 \times 4.5 \mathrm{~m}$ areas.

\section{Cover crop management}

Cover crops were sown in April 2018 and May 2019. In 2018, basic fertilization was used in all treatments with 20,30 and $26 \mathrm{~kg} \mathrm{ha}^{-1}$ of $\mathrm{N}, \mathrm{P}$ and $\mathrm{K}$, respectively. In 2019, the cover crops were sown without fertilizers because of the absence of crops of economic interest. Sowing density was $6 \mathrm{~kg} \mathrm{ha}^{-1}$ for ruzigrass (Urochloa ruziziensis), $2.2 \mathrm{~kg} \mathrm{ha}^{-1}$ for 
lime-yellow pea (Macrotyloma axillara cv. Java), $90 \mathrm{~kg} \mathrm{ha}^{-1}$ for black velvet bean (Mucuna pruriens), and $18 \mathrm{~kg} \mathrm{ha}^{-1}$ for millet (Pennisetum mericanum). The same quantities were used in single and intercropped sowings. In September 2018, $1.7 \mathrm{t} \mathrm{ha}^{-1}$ of dolomitic limestone was applied. In September 2019, 1 ton ha-1 of phosphogypsum was applied. Desiccations of cover crops were performed in September 2018 and October 2019 using the non-selective herbicide glyphosate (1.44 L ha ${ }^{-1}$ of a.i).

\section{Cotton management}

Cotton sowing (FM 983GLT, late cultivar) was performed on November 22, 2018, and November 28, 2019, with $0.90 \mathrm{~m}$ spacing between lines and eight seeds per linear meter. For seeding fertilization, 25 and $55 \mathrm{~kg} \mathrm{ha}^{-1}$ of $\mathrm{N}$ and $\mathrm{P}$ were used, respectively (monoammonium phosphate). Thirty days after emergence (DAE), $1.8 \mathrm{~kg} \mathrm{ha}^{-1}$ of boron (Ulexita) was applied. Potassium fertilizer was applied 25 and $60 \mathrm{DAE}$, with $50 \mathrm{~kg} \mathrm{ha}^{-1}$ of $\mathrm{K}$ (potassium chloride) for each application. Nitrogen fertilization was applied 25 and 45 DAE. In this period, elemental sulfur was applied in the conventional urea plots to balance the sulfur supplied via CRU. The management of pests, diseases, and growth regulator was performed according to the needs of the crop, with the same management practices for all treatments.

\section{Cover crop evaluations}

After the desiccation of the cover crops, shoots and roots were collected from three subsamples per plot in an area of $0.2 \mathrm{~m}^{-2}$ for the shoot (straw) and $2000 \mathrm{~cm}^{-3}$ for the root $(0.10 \times 0.10 \times 0.20 \mathrm{~m})$. The root samples were washed in running water, and the shoot samples were submerged in distilled water. They were then dried in an oven for $72 \mathrm{~h}$ at $65^{\circ} \mathrm{C}$ and weighed on a precision scale $(0.01 \mathrm{~g})$. In the fallow, SG, G+G, G+L, and MIX systems, shoot dry weights and ratio (carbon:nitrogen) were 1.4 (44), 4.0 (45), 4.6 (50), 1.6 (42), and 3.6 (43) t ha ${ }^{-1}$ (2018); and 0.90 (25), 4.5 (30), 4.9 (36), 3.7 (24), and $5.1(28) \mathrm{t} \mathrm{ha}^{-1}$ (2019), respectively. For roots, we observed $0.94(65), 2.7$ (70), 2.8 (69), 0.95 (64), 3.2 (65) t ha ${ }^{-1}$ (2018); and 0.68 (44), 1.7 (49), 1.0 (50), 0.78 (42), and $1.1(40)$ t ha $^{-1}(2019)$.

\section{Evaluations of total $\mathbf{N}$ and inorganic $\mathbf{N}$ in the soil}

Soil sampling was done three times each year. Soil in the 0.00-0.20 m layer was collected and observed in two periods: ten days after desiccation of the cover crops and when the cotton was in full bloom. After the cotton harvest, soil samples were collected in the following layers of $0.00-0.10,0.10-0.20,0.20-0.40$ and $0.40-0.60 \mathrm{~m}$. All collections were performed with four subsamples in each experimental unit. Soon after collection, the samples were placed in a thermal box with ice. The samples were stored in a freezer until the moment of analysis.

Before the evaluations, the samples thawed for $30 \mathrm{~min}$ before weighing. To evaluate the inorganic $\mathrm{N}$ in the soil (nitrate and ammonium), $5 \mathrm{~g}$ of soil was weighed on a $0.01 \mathrm{~g}$ precision scale. Next, $50 \mathrm{~mL}$ of $\mathrm{KCl} 1 \mathrm{~mol} \mathrm{~L}^{-1}$ was added. It was then stirred for one hour in an orbital shaker. After filtration, a $25 \mathrm{~mL}$ aliquot was separated for distillation. Magnesium oxide $(0.2 \mathrm{~g})$ was used in the first distillation to extract the ammonium. Lard alloy $(0.2 \mathrm{~g})$ was used in the second distillation to extract nitrate. Sulfuric acid was used for titration. Nitrate and ammonium contents were expressed in $\mathrm{mg} \mathrm{kg}^{-1}$ (Cantarella and Trivelin, 2001a).

Kjeldahl method was used to evaluate total nitrogen; $1 \mathrm{~g}$ of soil was weighed and $1 \mathrm{mg}$ of permanganate was added to the digestion tubes. This was followed by $30 \mathrm{~s}$ of stirring. Then, $2 \mathrm{~mL}$ of sulfuric acid (1:1) and $500 \mathrm{mg}$ of reduced iron were added, and the tubes were taken to the digestion block for 40 min at $50{ }^{\circ} \mathrm{C}$. Next, the tubes were removed from the block, and $3 \mathrm{~mL}$ of concentrated sulfuric acid and $1 \mathrm{~g}$ of digesting 
mixture were added and stirred again for $30 \mathrm{~s}$. The tubes were then taken to the digestion block for four hours at $360^{\circ} \mathrm{C}$. One day after the samples had cooled, $50 \mathrm{~mL}$ of distilled water was added and stirred. A $20 \mathrm{~mL}$ aliquot was separated for distillation with sodium hydroxide. Titration was performed with sulfuric acid. Total $\mathrm{N}$ content was expressed in $\mathrm{mg} \mathrm{kg}^{-1}$ (Cantarella and Trivelin, 2001b). Correction of soil moisture was performed in all samples, using $5 \mathrm{~g}$ of soil and drying in an oven for $48 \mathrm{~h}$ at $105{ }^{\circ} \mathrm{C}$ and weighed on a precision scale $(0.01 \mathrm{~g})$.

Stock of total and inorganic $\mathrm{N}$ (nitrate and ammonium) of the soil was calculated with consideration of the soil $\mathrm{N}$ content $\left(\mathrm{mg} \mathrm{kg}^{-1}\right)$ and soil density in the layers of $0.00-0.10$, $0.10-0.20,0.20-0.40$ and $0.40-0.60 \mathrm{~m}$. Soil density was determined by collecting five random soil samples from each system, using steel rings of $0.05 \mathrm{~m}$ of diameter and $0.05 \mathrm{~m}$ of height. The average density was then calculated: 1.71, 1.65, 1.70, 1.70 and $1.69 \mathrm{~g} \mathrm{dm}^{-3}$ in fallow, SG, G+G, G+L, and MIX systems, respectively. The $N$ stock in the soil was expressed in $\mathrm{kg} \mathrm{ha}^{-1}$.

\section{Data analysis}

After performing the Shapiro-Wilk normality test, the data were submitted to ANOVA. Statistical analysis was performed from variance analysis and treatment averages that were compared by the t-Test (LSD) at $5 \%$ probability $(p<0.05)$.

\section{RESULTS}

\section{Effects of cover crops on soil $\mathrm{N}$ content before cotton sowing}

Total $\mathrm{N}$ stock in fallow was $17 \%$ lower than in systems with cover crops (averages in the two crop seasons) (Figure 1a). Systems with legumes had the highest inorganic $\mathrm{N}$ and ammonium stock in the soil (Figure $1 \mathrm{~b}$ ). Despite having high inorganic $\mathrm{N}$ stock in the soil, the MIX system had low nitrate stock. The MIX system had the highest ammonium/nitrate ratio in both years. Similar characteristics were observed with the $G+L$ system in 2019/2020 (0.00-0.20 m) (Figure 1). Grass systems (with one or two species) had the lowest percentages of inorganic $\mathrm{N}$ in relation to the total soil $\mathrm{N}$ (Figure $1 \mathrm{f}$ ).

\section{Effects of $\mathbf{N}$ sources and $\mathbf{N}$ doses in different systems on soil $\mathbf{N}$ stock at peak cotton flowering}

In 2018/2019, CRU application increased total $\mathrm{N}$ stock in the soil by $11 \%$ (average of all N doses) in the SG and MIX systems. In 2019/2020, CRU application increased total $\mathrm{N}$ stock by an average of $8 \%$ in all systems (Table 1 ). In the first year, CRU application resulted in less inorganic $\mathrm{N}$ stock than conventional urea, except in the MIX system (average from all applied $\mathrm{N}$ doses). In the second year, this effect only occurred with high doses of $\mathrm{N}\left(130 \mathrm{~kg} \mathrm{ha}^{-1}\right)$ in systems without legumes (fallow, SG and G+G) (Table 1).

Nitrogen fertilization increased the nitrate stock in the soil, regardless of the $\mathrm{N}$ source, system, or crop season (Table 2). In 2018/2019, the ammonium stock in the soil increased in fallow and $\mathrm{G}+\mathrm{L}$ systems with CRU application, SG systems with conventional urea, and $\mathrm{G}+\mathrm{G}$ and $\mathrm{MIX}$ systems with both CRU application and conventional urea application. In 2019/2020, ammonium stock only increased in fallow systems; these increases occurred with both CRU and conventional urea (Table 2). In the first crop season, CRU application generally resulted in lower nitrate and ammonium availability than conventional urea (2018/2019). This was observed in the MIX system; CRU application resulted in $14 \%$ less ammonium stock (average from all applied $\mathrm{N}$ doses) than with conventional urea. Low ammonium availability from CRU application was also observed in $G+G$ and $G+L$ systems at $70 \mathrm{~kg} \mathrm{ha}^{-1}$ of $\mathrm{N}$ and $\mathrm{G}+\mathrm{G}$ systems at $130 \mathrm{~kg} \mathrm{ha}^{-1}$ of N. With the fallow system in the 2018/2019 crop season, CRU application resulted in $26 \%$ less nitrate stock (average from all applied $\mathrm{N}$ doses) than with conventional urea (Table 2). 


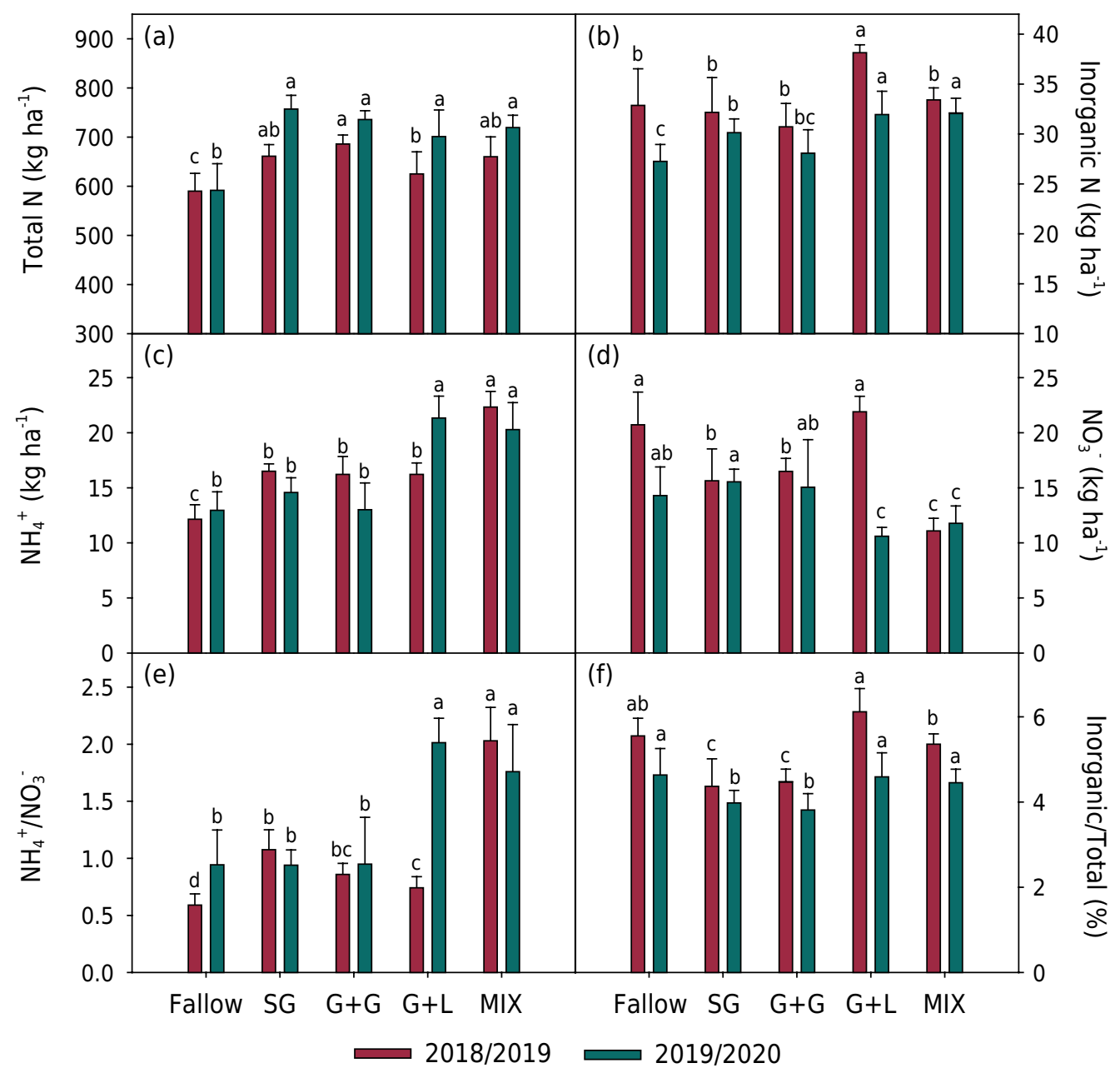

Figure 1. Stock of total nitrogen, inorganic nitrogen, ammonium and nitrate in the soil (0.00-0.20 m): the relationship between ammonium/nitrate; and the relation between the percentage of inorganic nitrogen to total nitrogen in the soil, in cotton pre-sowing. SG: single grass; G+G: grass + grass; $\mathrm{G}+\mathrm{L}$ : grass + legume; MIX: three species mixtures.

\section{Effect of $\mathbf{N}$ sources and $\mathbf{N}$ doses in different systems on soil $\mathbf{N}$ stock after cotton harvest}

Samples collected after the 2018/2019 cotton harvest showed that CRU application increased ammonium stock in the soil by an average of $22 \%\left(14.3 \mathrm{~kg} \mathrm{ha}^{-1}\right)$ (average of all applied $\mathrm{N}$ doses) in the $0.00-0.60$ m layer for the $\mathrm{SG}, \mathrm{G}+\mathrm{G}$ and $\mathrm{G}+\mathrm{L}$ systems, when compared to conventional urea. In the second crop season (2019/2020), ammonium stock was $13 \%$ higher $\left(9.8 \mathrm{~kg} \mathrm{ha}^{-1}\right)$ from CRU application than conventional urea application (average of all systems and applied $\mathrm{N}$ doses) (Table 3). In the first crop season (2018/2019), nitrate stock in the MIX system was $14 \%$ higher (11.9 $\left.\mathrm{kg} \mathrm{ha}^{-1}\right)$ from CRU application than conventional urea application. In the second crop season (2019/2020), nitrate stock was $17 \%$ higher ( $14.2 \mathrm{~kg} \mathrm{ha}^{-1}$ ) (average of all applied $\mathrm{N}$ doses) from CRU application than conventional urea (Table 3 ). When compared to conventional urea, CRU application increased inorganic $\mathrm{N}$ (nitrate+ammonium) in the soil by $12 \%$ after the cotton harvest at 0.00-0.60 m (average of all applied $\mathrm{N}$ doses, systems, and crop seasons) (Table 3).

As expected, increasing $\mathrm{N}$ doses $\left(70-130 \mathrm{~kg} \mathrm{ha}^{-1}\right)$ raised ammonium and nitrate stock in the soil with all systems, $\mathrm{N}$ sources, and crop seasons (Table 3 ). With the application of $130 \mathrm{~kg} \mathrm{ha}^{-1}$ of $\mathrm{N}$ via CRU, the nitrate stock was higher than $120 \mathrm{~kg} \mathrm{ha}^{-1}$ in the fallow, SG, and G+L systems in 2018/2019. The application of $130 \mathrm{~kg} \mathrm{ha}^{-1}$ of $\mathrm{N}$ with CRU increased ammonium stock to higher than $80 \mathrm{~kg} \mathrm{ha}^{-1}$ in G+G and MIX systems in 2018/2019 and all systems in 2019/2020 (Table 3). 
Table 1. Stock of total nitrogen and inorganic nitrogen in the soil (0.00-0.20 m) during the cotton flowering period

\begin{tabular}{|c|c|c|c|c|c|c|c|c|}
\hline \multirow{2}{*}{ Nitrogen } & \multicolumn{2}{|c|}{ Total N } & \multicolumn{2}{|c|}{ Inorganic N } & \multicolumn{2}{|c|}{ Total N } & \multicolumn{2}{|c|}{ Inorganic N } \\
\hline & \multicolumn{4}{|c|}{$2018 / 2019$} & \multicolumn{4}{|c|}{$2019 / 2020$} \\
\hline \multirow[t]{3}{*}{$\mathrm{kg} \mathrm{ha}^{-1}$} & \multicolumn{8}{|c|}{$\mathrm{kg} \mathrm{ha}^{-1}$} \\
\hline & \multicolumn{8}{|c|}{ Fallow } \\
\hline & Urea & CRU & Urea & CRU & Urea & CRU & Urea & CRU \\
\hline 70 & $587 \mathrm{Ab}$ & $566 \mathrm{Bb}$ & $28 \mathrm{Ab}$ & $26 \mathrm{Bb}$ & $661 \mathrm{Bb}$ & $776 \mathrm{Ab}$ & $28 \mathrm{AC}$ & $31 \mathrm{Ab}$ \\
\hline 100 & $638 \mathrm{Ba}$ & $691 \mathrm{Aa}$ & 33 Aab & $30 \mathrm{Bb}$ & $698 \mathrm{Ba}$ & $809 \mathrm{Aa}$ & $39 \mathrm{Ab}$ & 39 Aab \\
\hline 130 & $640 \mathrm{Ba}$ & $703 \mathrm{Aa}$ & $35 \mathrm{Aa}$ & $32 \mathrm{Ba}$ & $702 \mathrm{Ba}$ & $815 \mathrm{Aa}$ & $49 \mathrm{Aa}$ & $44 \mathrm{Ba}$ \\
\hline \multirow[t]{2}{*}{ CV (\%) } & \multicolumn{2}{|c|}{5.2} & \multicolumn{2}{|c|}{8.2} & \multicolumn{2}{|c|}{7.3} & \multicolumn{2}{|c|}{15.2} \\
\hline & \multicolumn{8}{|c|}{ Single grass } \\
\hline 70 & $555 \mathrm{Ba}$ & $641 \mathrm{Aa}$ & $28 \mathrm{AC}$ & $26 \mathrm{Ba}$ & $771 \mathrm{Ba}$ & $855 \mathrm{Aa}$ & $44 \mathrm{Ab}$ & $42 \mathrm{Ab}$ \\
\hline 100 & $560 \mathrm{Ba}$ & $640 \mathrm{Aa}$ & $35 A b$ & $27 \mathrm{Ba}$ & $767 \mathrm{Ba}$ & $839 \mathrm{Aa}$ & $47 \mathrm{Aab}$ & $44 \mathrm{Ab}$ \\
\hline 130 & $564 \mathrm{Ba}$ & $660 \mathrm{Aa}$ & $49 \mathrm{Aa}$ & $29 \mathrm{Ba}$ & $790 \mathrm{Ba}$ & $846 \mathrm{Aa}$ & $54 \mathrm{Aa}$ & $50 \mathrm{Ba}$ \\
\hline \multirow[t]{2}{*}{ CV $(\%)$} & \multicolumn{2}{|c|}{5.5} & \multicolumn{2}{|c|}{9.4} & \multicolumn{2}{|c|}{8.3} & \multicolumn{2}{|c|}{11.6} \\
\hline & \multicolumn{8}{|c|}{ Grass + grass } \\
\hline 70 & $655 \mathrm{Ba}$ & $701 \mathrm{Aa}$ & $27 \mathrm{Ab}$ & $21 \mathrm{BC}$ & 793 Ва & $819 \mathrm{Aa}$ & $44 \mathrm{Ab}$ & $41 \mathrm{Ab}$ \\
\hline 100 & $694 \mathrm{Aa}$ & $708 \mathrm{Aa}$ & $34 \mathrm{Aa}$ & $29 \mathrm{Bb}$ & $778 \mathrm{Ba}$ & $829 \mathrm{Aa}$ & $46 \mathrm{Ab}$ & $46 \mathrm{Aa}$ \\
\hline 130 & $690 \mathrm{Aa}$ & $725 \mathrm{Aa}$ & $41 \mathrm{Aa}$ & $37 \mathrm{Ba}$ & $711 \mathrm{Ba}$ & $861 \mathrm{Aa}$ & $50 \mathrm{Aa}$ & $48 \mathrm{Ba}$ \\
\hline \multirow[t]{2}{*}{ CV $(\%)$} & \multicolumn{2}{|c|}{5.5} & \multicolumn{2}{|c|}{6.5} & \multicolumn{2}{|c|}{5.5} & \multicolumn{2}{|c|}{12.5} \\
\hline & \multicolumn{8}{|c|}{ Grass + legume } \\
\hline 70 & $669 \mathrm{Aa}$ & $628 \mathrm{Aa}$ & $31 \mathrm{Ab}$ & $23 \mathrm{Bb}$ & $695 \mathrm{Ba}$ & $726 \mathrm{Aa}$ & $47 \mathrm{Ab}$ & $42 \mathrm{Ab}$ \\
\hline 100 & $701 \mathrm{Aa}$ & $666 \mathrm{Aa}$ & $32 \mathrm{Ab}$ & $32 \mathrm{Ba}$ & $691 \mathrm{Ba}$ & $744 \mathrm{Aa}$ & $52 \mathrm{Aab}$ & $48 \mathrm{Aab}$ \\
\hline 130 & $707 \mathrm{Aa}$ & $682 \mathrm{Aa}$ & $43 \mathrm{Aa}$ & $39 \mathrm{Ba}$ & $732 \mathrm{Ba}$ & $760 \mathrm{Aa}$ & $55 \mathrm{Aa}$ & $53 \mathrm{Aa}$ \\
\hline \multirow[t]{2}{*}{ CV $(\%)$} & \multicolumn{2}{|c|}{3.9} & & & 11 & & & \\
\hline & & & & & & & & \\
\hline 70 & $663 \mathrm{Ba}$ & $733 \mathrm{Aa}$ & $36 \mathrm{Ab}$ & $32 \mathrm{Ab}$ & $783 \mathrm{Ba}$ & $835 \mathrm{Aa}$ & $45 \mathrm{Ab}$ & $43 \mathrm{Ab}$ \\
\hline 100 & $693 \mathrm{Ba}$ & $729 \mathrm{Aa}$ & $35 A b$ & $31 \mathrm{Ab}$ & $801 \mathrm{Ba}$ & $853 \mathrm{Aa}$ & $46 \mathrm{Ab}$ & $49 \mathrm{Aa}$ \\
\hline 130 & $702 \mathrm{Ba}$ & $730 \mathrm{Aa}$ & $42 \mathrm{Aa}$ & $40 \mathrm{Aa}$ & 808 Ba & $867 \mathrm{Aa}$ & $55 \mathrm{Aa}$ & $53 \mathrm{Aa}$ \\
\hline CV (\%) & & & & & & & & \\
\hline
\end{tabular}

Averages followed by the same letter did not show statistical difference in the t-Test $(p<0.05)$. Uppercase letters compare the nitrogen source of each dose. Lowercase letters compare the nitrogen doses of each source.

\section{Nitrate and ammonium content of the soil after cotton harvest}

Crop systems, $\mathrm{N}$ sources and doses affected the nitrate and ammonium contents in the two evaluated crop seasons (Table 4). We also observed that cover crop systems and $\mathrm{N}$ sources interacted with the nitrate and ammonium contents in all soil depths in 2018/2019 and at depths of $0.00-0.10$ and $0.10-0.20 \mathrm{~m}$ in 2019/2020 (Table 4).

Controlled-release urea was more efficient in preventing ammonium and nitrate leaching in both crop seasons when used with cover crop systems and low $\mathrm{N}$ doses (70 and $100 \mathrm{~kg} \mathrm{ha}^{-1}$ ) (Figures 2 and 3 ). In our study, we observed more nitrate leaching than ammonium leaching (Figures 2 and 3), especially in the 2019/2020 crop season. In 2019/2020, ammonium contents were highest in the 0.00-0.10 m layer, regardless of the treatment (Figures 3a, 3c, 3e, 3g and 3i). In 2019/2020, nitrate contents were highest in the $0.00-0.10 \mathrm{~m}$ layer only with CRU application and in cover crop systems of high biomass input (SG, G+G, and MIX) (Figures $3 d, 3 f$ and $3 j$ ).

Nitrate leaching was highest with conventional urea and high $\mathrm{N}$ doses $\left(130 \mathrm{~kg} \mathrm{ha}^{-1}\right)$; we observed $273 \%$ more nitrate in the $0.40-0.60 \mathrm{~m}$ layer than in the $0.00-0.10 \mathrm{~m}$. With 
Table 2. Stock of ammonium and nitrate in the soil $(0.00-0.20 \mathrm{~m})$ during the cotton flowering period

\begin{tabular}{|c|c|c|c|c|c|c|c|c|}
\hline \multirow{2}{*}{ Nitrogen } & \multicolumn{2}{|c|}{$\mathbf{N H}_{4}{ }^{+}$} & \multicolumn{2}{|c|}{$\mathrm{NO}_{3}^{-}$} & \multicolumn{2}{|c|}{$\mathbf{N H}_{4}{ }^{+}$} & \multicolumn{2}{|c|}{$\mathrm{NO}_{3}^{-}$} \\
\hline & \multicolumn{4}{|c|}{$2018 / 2019$} & \multicolumn{4}{|c|}{$2019 / 2020$} \\
\hline \multirow[t]{2}{*}{$\mathrm{kg} \mathrm{ha}^{-1}$} & 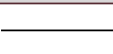 & & 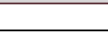 & $\mathrm{kc}$ & $a^{-1}$ & & & \\
\hline & Urea & CRU & Urea & CRU & Urea & CRU & Urea & CRU \\
\hline 70 & $12 \mathrm{Aa}$ & $12 \mathrm{Ab}$ & $16 \mathrm{Ab}$ & $14 \mathrm{Bb}$ & $13 \mathrm{AC}$ & $13 \mathrm{Ab}$ & $16 \mathrm{Ab}$ & $18 \mathrm{Aab}$ \\
\hline 100 & $13 \mathrm{Aa}$ & $15 \mathrm{Aa}$ & $20 \mathrm{Aa}$ & $15 \mathrm{Bb}$ & $18 A b$ & $16 \mathrm{Ab}$ & $22 \mathrm{Aa}$ & $21 \mathrm{Aab}$ \\
\hline 130 & $14 \mathrm{Aa}$ & $15 \mathrm{Aa}$ & $21 \mathrm{Aa}$ & $16 \mathrm{Ba}$ & $21 \mathrm{Aa}$ & $21 \mathrm{Aa}$ & $27 \mathrm{Aa}$ & $22 \mathrm{Aa}$ \\
\hline CV (\%) & \multicolumn{2}{|c|}{13.2} & \multicolumn{2}{|c|}{10.2} & \multicolumn{2}{|c|}{17.2} & \multicolumn{2}{|c|}{19.8} \\
\hline 70 & $12 \mathrm{AC}$ & $11 \mathrm{Aa}$ & $16 \mathrm{AC}$ & $16 \mathrm{Ab}$ & $23 A a$ & $23 \mathrm{Aa}$ & $21 \mathrm{Ab}$ & $20 \mathrm{Ab}$ \\
\hline 100 & $17 \mathrm{Aa}$ & $13 \mathrm{Ba}$ & $18 \mathrm{Ab}$ & $14 \mathrm{Bb}$ & $27 \mathrm{Aa}$ & $22 \mathrm{Aa}$ & $21 \mathrm{Ab}$ & $22 \mathrm{Ab}$ \\
\hline 130 & $24 \mathrm{Aa}$ & $12 \mathrm{Ba}$ & $26 \mathrm{Aa}$ & $17 \mathrm{Ba}$ & $28 \mathrm{Aa}$ & $25 \mathrm{Aa}$ & $26 \mathrm{Aa}$ & $25 \mathrm{Aa}$ \\
\hline CV (\%) & \multicolumn{2}{|c|}{13.4} & \multicolumn{2}{|c|}{9.7} & \multicolumn{2}{|c|}{17.2} & \multicolumn{2}{|c|}{11.7} \\
\hline 70 & $12 \mathrm{Ab}$ & $9 \mathrm{BC}$ & $15 \mathrm{Ac}$ & $12 \mathrm{Bb}$ & $23 \mathrm{Aa}$ & $22 \mathrm{Aa}$ & $21 \mathrm{Ab}$ & $20 \mathrm{Ab}$ \\
\hline 100 & $12 A b$ & $12 \mathrm{Ab}$ & $22 \mathrm{Aa}$ & $17 \mathrm{Aa}$ & $22 \mathrm{Aa}$ & $23 \mathrm{Aa}$ & $24 \mathrm{Aa}$ & $23 \mathrm{Aa}$ \\
\hline 130 & $16 \mathrm{Aa}$ & $19 \mathrm{Aa}$ & $24 \mathrm{Aa}$ & $19 \mathrm{Aa}$ & $24 \mathrm{Aa}$ & $24 \mathrm{Aa}$ & $26 \mathrm{Aa}$ & $23 \mathrm{Aa}$ \\
\hline CV (\%) & \multicolumn{2}{|c|}{12.8} & \multicolumn{2}{|c|}{7.4} & \multicolumn{2}{|c|}{15.1} & \multicolumn{2}{|c|}{22.8} \\
\hline 70 & $15 \mathrm{Aa}$ & $11 \mathrm{BC}$ & $17 \mathrm{Ab}$ & $12 \mathrm{Bb}$ & $27 \mathrm{Aa}$ & $24 \mathrm{Aa}$ & $21 \mathrm{Ab}$ & $18 \mathrm{Ab}$ \\
\hline 100 & $16 \mathrm{Aa}$ & $18 \mathrm{Ab}$ & $16 \mathrm{Ab}$ & $14 \mathrm{Aa}$ & $27 \mathrm{Aa}$ & $26 \mathrm{Aa}$ & 25 Aab & $22 \mathrm{Aa}$ \\
\hline 130 & $16 \mathrm{Ba}$ & $20 \mathrm{Aa}$ & $27 \mathrm{Aa}$ & $19 \mathrm{Ba}$ & $27 \mathrm{Aa}$ & $29 \mathrm{Aa}$ & $28 \mathrm{Aa}$ & $24 \mathrm{Aa}$ \\
\hline CV (\%) & \multicolumn{2}{|c|}{10.9} & \multicolumn{2}{|c|}{9.1} & \multicolumn{2}{|c|}{14.2} & \multicolumn{2}{|c|}{17.5} \\
\hline 70 & $20 \mathrm{Ab}$ & $18 \mathrm{Bb}$ & $16 \mathrm{Ab}$ & $14 \mathrm{Ab}$ & $28 \mathrm{Aa}$ & $24 \mathrm{Aa}$ & $17 \mathrm{Ab}$ & $17 \mathrm{Ab}$ \\
\hline 100 & $20 A b$ & $17 \mathrm{Bb}$ & $16 \mathrm{Ab}$ & $14 \mathrm{Ab}$ & $27 \mathrm{Aa}$ & $26 \mathrm{Aa}$ & $19 \mathrm{Ab}$ & $23 \mathrm{Aa}$ \\
\hline 130 & $23 \mathrm{Aa}$ & $20 \mathrm{Ba}$ & $20 \mathrm{Aa}$ & $19 \mathrm{Aa}$ & $28 \mathrm{Aa}$ & $30 \mathrm{Aa}$ & $27 \mathrm{Aa}$ & $23 \mathrm{Aa}$ \\
\hline CV (\%) & \multicolumn{2}{|c|}{8.5} & \multicolumn{2}{|c|}{10.2} & \multicolumn{2}{|c|}{18.7} & \multicolumn{2}{|c|}{15.7} \\
\hline
\end{tabular}

Averages followed by the same letter did not show statistical difference in the t-Test (LSD) $(p<0.05)$. Uppercase letters compare the nitrogen source of each dose, and lowercase letters compare the nitrogen dose of each source.

CRU application and the same $\mathrm{N}$ dose, there was less than a $37 \%$ difference between these layers (Figure $3 b$ ). More nitrate leaching occurred in the 2019/2020 crop season. There was $944 \mathrm{~mm}$ of rain in 2019/2020; $47 \%$ more than the previous crop season. As previously mentioned, ammonium contents were highest in the $0.00-0.10 \mathrm{~m}$ layer in 2019/2020, regardless of the $\mathrm{N}$ source, $\mathrm{N}$ dose, or system (Figure 3). However, the application of $70 \mathrm{~kg} \mathrm{ha}^{-1}$ of $\mathrm{N}$ with CRU resulted in higher $\mathrm{N}$ content in the topsoil (0.00-0.10 m) when compared to application of $130 \mathrm{~kg} \mathrm{ha}^{-1}$ of $\mathrm{N}$ via conventional urea.

\section{DISCUSSION}

The use of grasses and legumes as cover crops is an effective strategy to increase total $\mathrm{N}$ in the soil (Figure 1a). This has been reported in various studies (Mitchell et al., 2017; Yao et al., 2019; Silva et al., 2020). However, the availability of inorganic $\mathrm{N}$ is low in grass systems with high $\mathrm{C}: \mathrm{N}$ ratios in sandy soil with low organic matter (Figure $1 \mathrm{~b}$ ), as soil microorganisms immobilize $\mathrm{N}$ in the soil and cause carbon degradation of straw and roots of cover crops. This effect can impair crop yield (Chu et al., 2017; Rocha et al., 
Table 3. Stock of ammonium $\left(\mathrm{NH}_{4}{ }^{+}\right)$and nitrate $\left(\mathrm{NO}_{3}{ }^{-}\right)$of the soil $(0.00-0.60 \mathrm{~m})$ after the cotton harvest

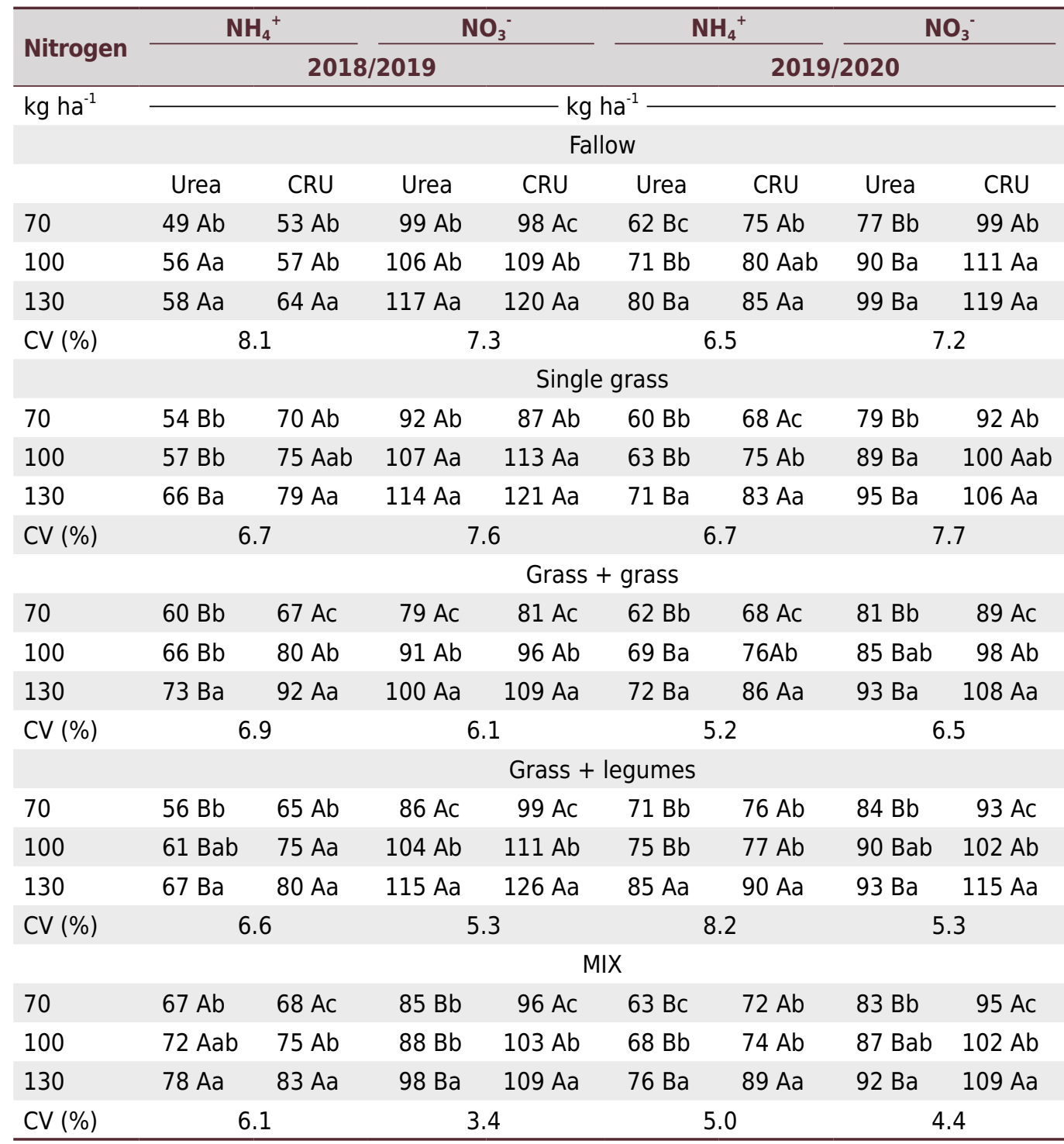

Averages followed by the same letter did not show statistical difference in the t-Test (LSD) $(p<0.05)$. Uppercase letters compare the nitrogen source of each dose, and lowercase letters compare the nitrogen dose of each source.

2019; Momesso et al., 2019) due to the reduced availability of $\mathrm{N}$ in the soil (Figure 1 ). This reduces initial cotton growth (Echer et al., 2012) and cotton yield, especially in sandy soils with low $\mathrm{N}$ stock (Cordeiro et al., 2021b). Even with cover crops, total $\mathrm{N}$ stock in sandy soil is low in the arable layer (0.00-0.20 m) (between 590 and $760 \mathrm{~kg} \mathrm{ha}^{-1}$ ) (Figure $1 \mathrm{a}$ and Table 1), as observed in other studies (Cordeiro and Echer., 2019; Silva et al., 2020).

Combinations of legumes with low $\mathrm{C}: \mathrm{N}$ ratios and grasses with high biomass production and high $\mathrm{C}: \mathrm{N}$ ratios are the best options for increasing quantities of total $\mathrm{N}$ and inorganic $\mathrm{N}$ in the soil (Figure 1). Using a single legume with low dry matter content and a low $\mathrm{C}: \mathrm{N}$ ratio causes rapid mineralization of $\mathrm{N}$ and $\mathrm{C}$ (Li et al., 2013). In tropical climates with sandy soil, this undesirable effect leads to lower total $\mathrm{C}$ and $\mathrm{N}$ stock in the soil (Campos et al., 2020), as soil organic matter mineralization occurs naturally in these environments (Liyanage et al., 2020). Furthermore, in systems with higher doses of nitrogen fertilizers and cover crops with low dry matter production, N's movement in the soil is greater, mostly nitrate (Figures 2 and 3).

The nitrification process transforms ammonium into nitrate; this effect is accelerated in sandy soil in a tropical climate and increases nitrate content in the soil when compared 
Table 4. Variance analysis summary of the ammonium and nitrate content in the soil at the layers of $0.00-0.10,0.10-0.20,0.20-0.40$, and $0.40-0.60 \mathrm{~m}$ with different crop rotation systems, nitrogen sources, nitrogen doses, and interactions

\begin{tabular}{|c|c|c|c|c|}
\hline \multirow{2}{*}{$\begin{array}{l}\text { Source of variation } \\
\text { Depth }\end{array}$} & $\mathbf{N H}_{4}^{+}$ & $\mathrm{NO}_{3}{ }^{-}$ & $\mathrm{NH}_{4}{ }^{+}$ & $\mathrm{NO}_{3}^{-}$ \\
\hline & \multicolumn{2}{|c|}{$2018 / 2019$} & \multicolumn{2}{|c|}{$2019 / 2020$} \\
\hline \multicolumn{5}{|l|}{$0.00-0.10 \mathrm{~m}$} \\
\hline Systems (S) & $* * *$ & $* * *$ & $* * *$ & $* * *$ \\
\hline Doses of $N(D N)$ & $* * *$ & $* * *$ & *** & $* *$ \\
\hline Source of N (SN) & $* * *$ & $* * *$ & $* * *$ & $* * *$ \\
\hline$S \times D N$ & $*$ & NS & NS & NS \\
\hline $\mathrm{S} \times \mathrm{SN}$ & $* * *$ & $* * *$ & $*$ & $*$ \\
\hline $\mathrm{DN} \times \mathrm{SN}$ & $*$ & NS & NS & $* *$ \\
\hline $\mathrm{S} \times \mathrm{DN} \times \mathrm{SN}$ & NS & NS & NS & NS \\
\hline CV\% & 10.3 & 11.9 & 9.1 & 11.2 \\
\hline \multicolumn{5}{|l|}{$0.10-0.20 \mathrm{~m}$} \\
\hline Systems (S) & $* * *$ & $* *$ & $*$ & * \\
\hline Doses of $N(D N)$ & $* * *$ & $* * *$ & $* *$ & $* * *$ \\
\hline Source of N (SN) & $* * *$ & $* * *$ & $* * *$ & $* * *$ \\
\hline $\mathrm{S} \times \mathrm{DN}$ & NS & $*$ & $*$ & $* * *$ \\
\hline $\mathrm{S} \times \mathrm{SN}$ & $* * *$ & $* * *$ & $*$ & $* * *$ \\
\hline $\mathrm{DN} \times \mathrm{SN}$ & NS & NS & NS & NS \\
\hline $\mathrm{S} \times \mathrm{DN} \times \mathrm{SN}$ & NS & NS & NS & NS \\
\hline CV\% & 11.2 & 12.5 & 12.7 & 12.5 \\
\hline \multicolumn{5}{|l|}{$0.20-0.40 \mathrm{~m}$} \\
\hline Systems (S) & $* * *$ & $* * *$ & *** & $* * *$ \\
\hline Doses of $N(D N)$ & $* * *$ & $* * *$ & $* * *$ & $* * *$ \\
\hline Source of N (SN) & $*$ & $*$ & $*$ & $* * *$ \\
\hline$S \times D N$ & NS & $* * *$ & NS & $* * *$ \\
\hline $\mathrm{S} \times \mathrm{SN}$ & $*$ & $* * *$ & NS & NS \\
\hline $\mathrm{DN} \times \mathrm{SN}$ & NS & NS & NS & NS \\
\hline $\mathrm{S} \times \mathrm{DN} \times \mathrm{SN}$ & NS & NS & NS & NS \\
\hline CV\% & 16.6 & 13.2 & 19.6 & 11.9 \\
\hline \multicolumn{5}{|l|}{$0.40-0.60 \mathrm{~m}$} \\
\hline Systems (S) & $* * *$ & $* * *$ & *** & $* * *$ \\
\hline Doses of $N(D N)$ & $* * *$ & $* * *$ & $* * *$ & $* * *$ \\
\hline Source of N (SN) & $* * *$ & $* * *$ & *** & $* * *$ \\
\hline$S \times D N$ & NS & $*$ & * & $* * *$ \\
\hline $\mathrm{S} \times \mathrm{SN}$ & $* *$ & $* * *$ & NS & NS \\
\hline $\mathrm{DN} \times \mathrm{SN}$ & NS & NS & NS & NS \\
\hline $\mathrm{S} \times \mathrm{DN} \times \mathrm{SN}$ & NS & NS & NS & NS \\
\hline CV\% & 18.4 & 11.0 & 16.9 & 11.2 \\
\hline
\end{tabular}

***: significant at $0.1 \%$.**: significant at $1 \%$. : significant at $5 \%$. NS: Not significant.

to ammonium content (Campos et al., 2020), which can intensify nitrate leaching by up to $33 \mathrm{~kg} \mathrm{ha}^{-1}$ per year (Rosolem et al., 2018). Thus, more nitrate is lost than ammonium (Figures 2 and 3 ). Ammonium loss can be further reduced by using techniques that elevate organic material, as ammonium is a cation stored in the CEC of the soil (Teutscherova et al., 2018). Combinations of grass and legumes increased ammonium stock in relation to nitrates in the arable soil layer $(0.00-0.20 \mathrm{~m})$ (Figure 1$)$. This suggests 


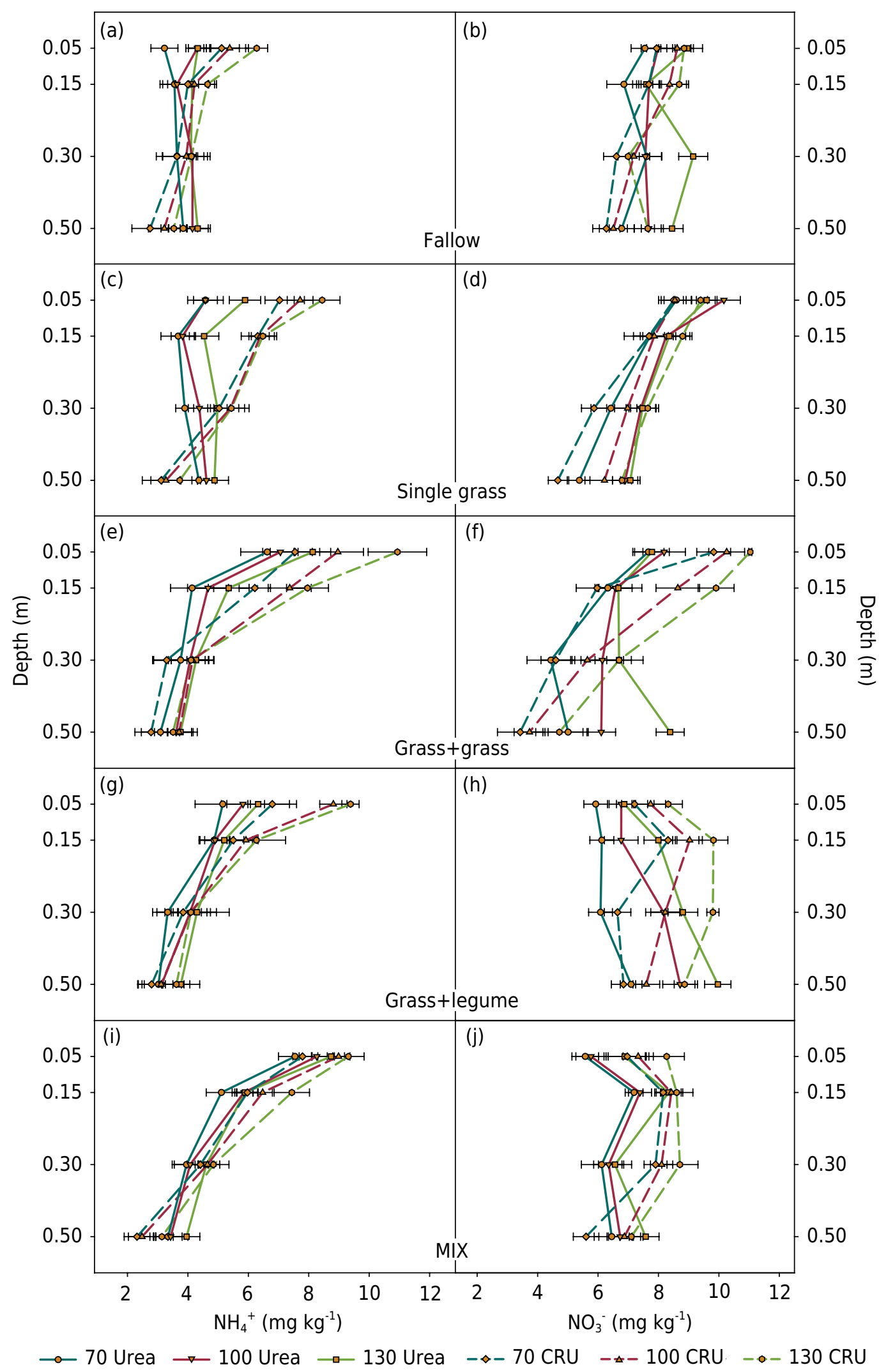

Figure 2. Inorganic nitrogen contents in the soil $\left(\mathrm{NH}_{4}{ }^{+}\right.$and $\left.\mathrm{NO}_{3}{ }^{-}\right)$after cotton harvest from the $2018 / 2019$ crop season. Horizontal bars represent standard error of the mean.

that using an ample diversity of cover crop species can both reduce $\mathrm{N}$ nitrification and increase ammonium content via biological nitrogen fixation (BNF). Tropical grasses are reportedly more efficient in reducing $\mathrm{N}$ nitrification in the soil (Subbarao et al., 2007; Subbarao et al., 2009), regardless of the grass species (Rocha et al., 2019). 


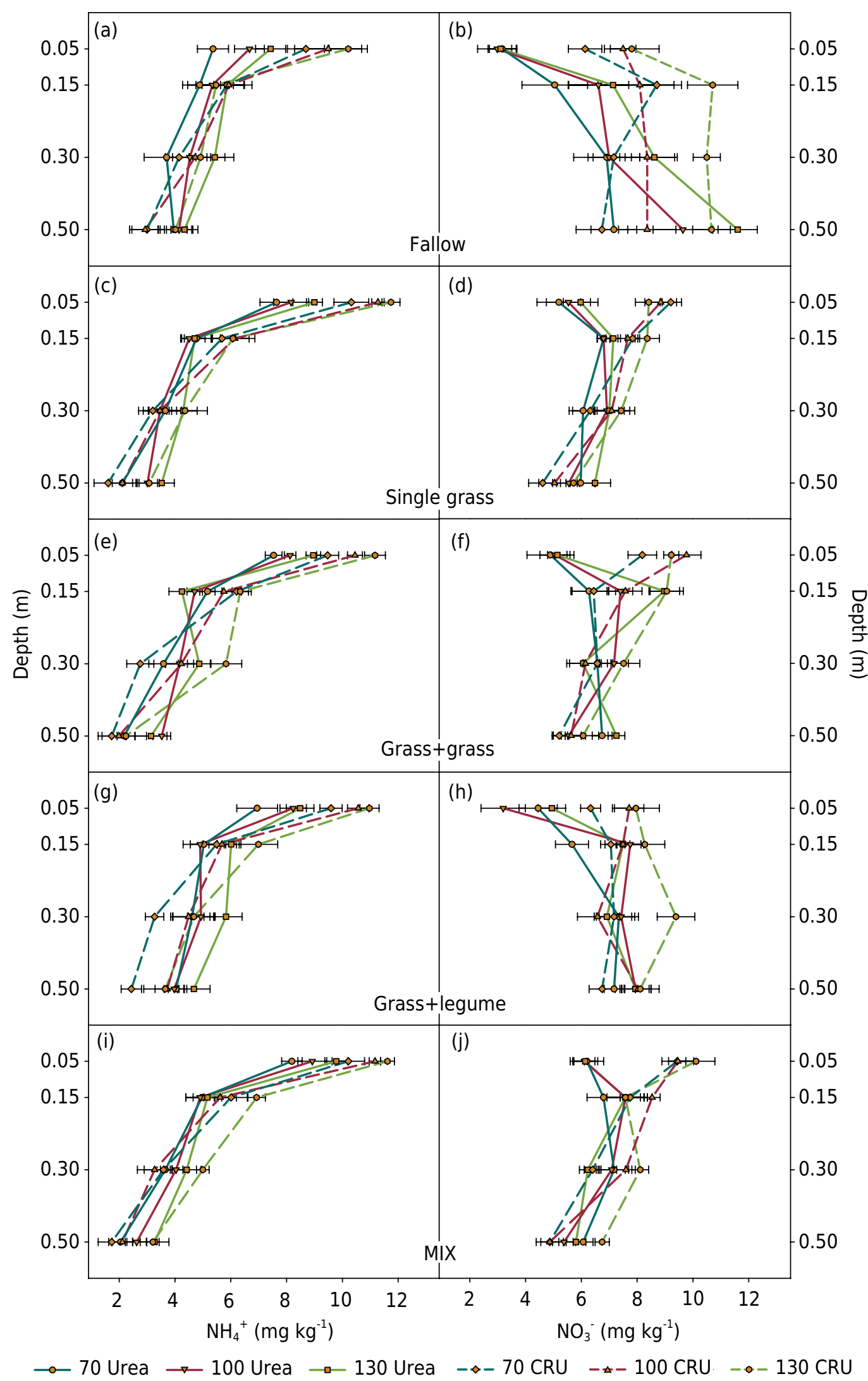

Figure 3. Soil Inorganic nitrogen $\left(\mathrm{NH}_{4}{ }^{+}\right.$and $\left.\mathrm{NO}_{3}{ }^{-}\right)$after the cotton harvest in the $2019 / 2020 \mathrm{crop}$ season. Horizontal bars represent the standard error of the mean.

Nitrogen fertilization increases soil N stock (Suzuki et al., 2017; Cordeiro and Echer, 2019; Kumar et al., 2019; Cordeiro et al., 2021a). However, we observed that this technique has a greater impact in systems without cover crops, as $\mathrm{N}$ fertilization increased total $\mathrm{N}$ 
stock in only fallow systems (Table 1). Cover crops can reduce the necessity of $\mathrm{N}$ fertilizers because of their capacity to increase soil $\mathrm{N}$ stock. Thus, cover crops are more economical than traditional fertilizers. Controlled-release urea application increased total $\mathrm{N}$ stock in the soil by $8 \%$ at the end of the second crop season (Table 1). Controlled-release urea application caused less impact on total $\mathrm{N}$ stock in the first crop season. A cumulative effect likely increased $\mathrm{N}$ stock in the second crop season, as CRU application reduces $\mathrm{N}$ loss and can increase total $\mathrm{N}$ by up to $12 \%$ (Geng et al., 2016b).

In the year with less precipitation (2018/2019), CRU application reduced the availability of inorganic $\mathrm{N}$ in the soil during the bloom period, principally in fallow systems (Tables 1 and 2). Controlled-release urea efficiency is highly dependent on moisture in the surface soil (Zheng et al., 2016) for oxidation of the sulfur that covers urea granules. Which can also be affected by soil pH, but with less importance for this study, since the amount of $\mathrm{S}$ contained in fertilizers is low. Therefore, in soils with low levels of inorganic $\mathrm{N}$ and years with low water availability, the delayed release of $\mathrm{N}$ from CRU application can limit $\mathrm{N}$ absorption in the flowering period. The effect on yield depends on the severity of water restriction, as lack of water also limits nutrient absorption and plant growth.

After cotton harvest, we observed that CRU application increased nitrate and ammonium availability by an average of $12 \%$ at depths up to $0.60 \mathrm{~m}$ below the surface (Table 4). The $\mathrm{N}$ release rate from CRU application can explain differences between $\mathrm{N}$ stock in the flowering period and after collection, as the rate release depends on the thickness of the elemental sulfur layer of the granules. Significant $N$ release can occur even after 90 days of CRU application (Zheng et al., 2016). The increase of ammonium and nitrate stock in the soil after harvest, as occurred with CRU application, represents the economic benefit of CRU application. The successive crop will require less fertilizer, as $\mathrm{N}$ cycling increases with cover crop use.

Various studies have reported that the use of cover crops (specifically grasses with high biomass input) in the shoot and root areas can reduce $\mathrm{N}$ leaching in the soil in tropical climates (Rosolem et al., 2018; Galdos et al., 2020; Rocha et al., 2020). Studies have also shown that CRU application reduces leaching, principally nitrate leaching (Tian et al., 2018; Zhang et al., 2018). However, in environments with tropical climates, high precipitation, and sandy soil, the isolated use of just one of these techniques (cover crops or CRU application) is not enough to efficiently reduce nitrate leaching (Figures 2 and 3). Our results demonstrate that combining cover crops with CRU application is necessary to reduce nitrate movement by using moderate doses of $\mathrm{N}$ as recommended for the region.

Ammonium movement can be reduced by using cover crop systems with high biomass input (SG, G+G and MIX), mainly in the second crop season. Increases in organic matter (Raphael et al., 2016), the consequential increase in cation exchange capacity (Sharma et al., 2018), and $\mathrm{NH}_{4}{ }^{+}$retention in the topsoil are all possible explanations of this result (Shaddox et al., 2016). However, with a high dose of $130 \mathrm{~kg} \mathrm{ha}^{-1}$ of $\mathrm{N}$, the ammonium movement was higher, even with the use of cover crops (Figures 2 and 3).

Even when $\mathrm{CRU}$ and cover crops were used, application of $\mathrm{N}$ doses above the recommended level increased nitrate movement in soil layers of $0.40-0.60 \mathrm{~m}$ in SG and G+L systems in 2018/2019 and G+L and MIX systems in 2019/2020 (Figures 2 and 3). This is a problem because the cotton root system is usually effective up to $0.40 \mathrm{~m}$, so a system without cover crops can result in nitrate losses in the $0.40-0.60 \mathrm{~m}$ layer.

\section{CONCLUSION}

The use of a diversity of cover crops increases the ratio of ammonium to nitrate in soil. Grass systems reduce the availability of inorganic N. Total $\mathrm{N}$ increases in systems with cover crops with high biomass input. Increasing the $\mathrm{N}$ dose raises inorganic $\mathrm{N}$ stock in the 
soil, but the application of $30 \%$ or more of the recommended dose for cotton in the region of our study intensified movement, for nitrate, mainly in systems without cover crops and use of conventional urea. After cotton harvest, we observed that controlled-release urea application resulted in $12 \%$ more inorganic $\mathrm{N}$ than from conventional urea application, which can reduce the consumption of $\mathrm{N}$ fertilizers in cotton crops.

\section{ACKNOWLEDGMENTS}

We thank the Foundation for Research Support of the State of São Paulo (FAPESP) for their support with the master's scholarship for the first author, process (2018/23770-0); Agrisus Foundation - Sustainable Agriculture for research funding, process (PA 2628/19); and São Paulo Association of Cotton Producers (APPA) for financial support.

\section{AUTHOR CONTRIBUTIONS}

Conceptualization: (DD Carlos Felipe dos Santos Cordeiro (equal) and (DD Fábio Rafael Echer (lead).

Data curation: (ID Carlos Felipe dos Santos Cordeiro (lead) and (iD) Daniel Rodela Rodrigues (supporting).

Formal analysis: (D) Carlos Felipe dos Santos Cordeiro (lead) and (D) Fábio Rafael Echer (equal).

Funding acquisition: (D) Fábio Rafael Echer (lead).

Investigation: (DD Ana Flávia de Souza Rorato (equal), (D) Carlos Felipe dos Santos Cordeiro (lead) and (D) Daniel Rodela Rodrigues (equal).

Methodology: (D) Ana Flávia de Souza Rorato (equal), (D) Carlos Felipe dos Santos Cordeiro (lead) and (D) Daniel Rodela Rodrigues (equal).

Project administration: (DD Fábio Rafael Echer (lead).

Resources: (D) Fábio Rafael Echer (lead).

Supervision: (iD Fábio Rafael Echer (lead).

Validation: (D) Carlos Felipe dos Santos Cordeiro (equal) and (D) Daniel Rodela Rodrigues (supporting).

Visualization: (D) Ana Flávia de Souza Rorato (equal), (D) Carlos Felipe dos Santos Cordeiro (equal), (D) Daniel Rodela Rodrigues (equal) and (D) Fábio Rafael Echer (equal).

Writing - original draft: (ID) Carlos Felipe dos Santos Cordeiro (lead) and (D) Fábio Rafael Echer (equal).

Writing - review \& editing: (D) Carlos Felipe dos Santos Cordeiro (equal) and (ID Fábio Rafael Echer (equal).

\section{REFERENCES}

Billen G, Garnier J, Lassaletta L. The nitrogen cascade from agricultural soils to the sea: Modelling nitrogen transfers at regional watershed and global scales. Phil Trans R Soc B. 2013;368:20130123. https://doi.org/10.1098/rstb.2013.0123

Bronson KF, Hunsaker DJ, Meisinger JJ, Rockholt SM, Thorp KR, Conley MM, Williams CF, Norton ER, Barnes EM. Improving nitrogen fertilizer use efficiency in subsurface drip-irrigated cotton in the Desert Southwest. Soil Sci Soc Am J. 2019;83:1712-21. https://doi.org/10.2136/sssaj2019.07.0210 
Campos A, Suárez G, Laborde J. Analyzing vegetation cover-induced organic matter mineralization dynamics in sandy soils from tropical dry coastal ecosystems. Catena. 2020;185:104264. https://doi.org/10.1016/j.catena.2019.104264

Cantarella H, Trivelin PCO. Determinação de nitrogênio total em solo. In: van Raij B, Andrade JC, Cantarella H, Quaggio JA, editors. Análise química para avaliação da fertilidade de solos tropicais. Campinas: Instituto Agronômico de Campinas; 2001b. p. 262-9.

Cantarella H, Trivelin PCO. Determinação do nitrogênio inorgânico em solo pelo método da destilação a vapor. In: van Raij B, Andrade JC, Cantarella H, Quaggio JA, editors. Análise química para avaliação da fertilidade de solos tropicais. Campinas: Instituto Agronômico de Campinas; 2001a. p. 270-6.

Chu M, Jagadamma S, Walker FR, Eash NS, Buschermohle MJ, Duncan LA. Effect of multispecies cover crop mixture on soil properties and crop yield. Agric Environ Lett. 2017;2:170030. https://doi.org/10.2134/ael2017.09.0030

Cordeiro CFS, Echer FR, Araujo FF. Cover crops impact crops yields by improving microbiological activity and fertility in sandy soil. J Soil Sci Plant Nutr. 2021b;21:1968-77. https://doi.org/10.1007/s42729-021-00494-0

Cordeiro CFS, Echer FR. Interactive effects of nitrogen-fixing bacteria inoculation and nitrogen fertilization on soybean yield in unfavorable edaphoclimatic environments. Sci Rep. 2019;9:15606. https://doi.org/10.1038/s41598-019-52131-7

Cordeiro CFS, Lopes BP, Batista GD, Araujo FF, Tiritan CS, Echer FR. Inoculation and nitrogen fertilization improve nitrogen soil stock and nutrition to soybeans in degraded pastures with sandy soil. Commun Soil Sci Plant Anal. 2021a;52:1388-98. https://doi.org/10.1080/00103624.2021.1885685

Echer FR, Castro GSA, Bogiani JC, Rosolem CA. Crescimento inicial e absorção de nutrientes pelo algodoeiro cultivado sobre a palhada de Brachiaria ruziziensis. Planta Daninha. 2012;30:783-90. https://doi.org/10.1590/S0100-83582012000400012

Echer FR, Cordeiro CFS, de la Torre EDJR. The effects of nitrogen, phosphorus, and potassium levels on the yield and fiber quality of cotton cultivars. J Plant Nutr. 2020;43:921-32. https://doi.org/10.1016/j.eja.2015.01.001

Galdos MV, Brown E, Rosolem CA, Pires LF, Hallett PD, Mooney SJ. Brachiaria species influence nitrate transport in soil by modifying soil structure with their root system. Sci Rep. 2020;10:5072. https://doi.org/10.1038/s41598-020-61986-0

Geng J, Ma Q, Chen J, Zhang M, Li C, Yang Y, Liu Z. Effects of polymer coated urea and sulfur fertilization on yield, nitrogen use efficiency and leaf senescence of cotton. Field Crop Res. 2016a;187:87-95. https://doi.org/10.1016/j.fcr.2015.12.010

Geng J, Chen J, Sun Y, Zheng W, Tian X, Yang Y, Li C, Zhang M. Controlled release urea improved nitrogen use efficiency and yield of wheat and corn. Agron J. 2016b;108:1666-73. https://doi.org/10.2134/agronj2015.0468

Kumar P, Lai L, Battaglia ML, Kumar S, Owens V, Fike J, Galbraith J, Hong CO, Farris R, Crawford J, Crawford J, Hansen J, Mayton H, Viands D. Impacts of nitrogen fertilization rate and landscape position on select soil properties in switchgrass field at four sites in the USA. Catena. 2019;180:183-93. https://doi.org/10.1016/j.catena.2019.04.028

Li LJ, Han XZ, You MY, Yuan YR, Ding XL, Qiao YF. Carbon and nitrogen mineralization patterns of two contrasting crop residues in a Mollisol: Effects of residue type and placement in soils. Eur J Soil Biol. 2013;54:1-6. https://doi.org/10.1016/j.ejsobi.2012.11.002

Liyanage A, Grace PR, Scheer C, Rosa D, Ranwala S, Rowlings DW. Carbon limits non-linear response of nitrous oxide $\left(\mathrm{N}_{2} \mathrm{O}\right)$ to increasing $\mathrm{N}$ inputs in a highly-weathered tropical soil in Sri Lanka. Agr Ecosyst Environ. 2020;292:106808. https://doi.org/10.1016/j.agee.2019.106808

Mariano E, Ana Filho CRS, Bortoletto-Santos R, Bendassoli JA, Trivelin PCO. Ammonia losses following surface application of enhanced-efficiency nitrogen fertilizers and urea. Atmos Environ. 2019;203:242-51. https://doi.org/10.1016/j.atmosenv.2019.02.003

Minato EA, Cassim BMAR, Besen MR, Mazzi FL, Inoue TT, Batista M.A. Controlled-release nitrogen fertilizers: characterization, ammonia volatilization, and effects on second-season corn. Rev Bras Cienc Solo. 2020;44:e0190108. https://doi.org/10.36783/18069657rbcs20190108 
Mitchell JP, Shrestha A, Mathesius K, Scow KM, Southard RJ, Haney RL, Schmid R, Munk DS, Horwath WR. Cover cropping and no-tillage improve soil health in an arid irrigated cropping system in California's San Joaquin Valley, USA. Soil Till Res. 2017;165:325-35. https://doi.org/10.1016/j.still.2016.09.001

Momesso L, Crusciol CAC, Soratto RP, Vyn TJ, Tanaka KS, Costa CHM, Ferrari Neto J, Cantarella $\mathrm{H}$. Impacts of nitrogen management on no-till maize production following forage cover crops. Agron J. 2019;111:639-49. https://doi.org/10.2134/agronj2018.03.0201

Raphael JP, Calonego JC, Milori DMB, Rosolem CA. Soil organic matter in crop rotations under no-till. Soil Till Res. 2016;155:45-53. https://doi.org/10.1016/j.still.2015.07.020

Rocha KF, Souza M, Almeida DS, Chadwick DR, Jones DL, Mooney SJ, Rosolem CA. Cover crops affect the partial nitrogen balance in a maize-forage cropping system. Geoderma. 2020;360:114000. https://doi.org/10.1016/j.geoderma.2019.114000

Rocha KF, Mariano E, Grassmann CS, Trivelin PC, Rosolem CA. Fate of ${ }^{15} \mathrm{~N}$ fertilizer applied to maize in rotation with tropical forage grasses. Field Crop Res. 2019;238:35-44. https://doi.org/10.1016/j.fcr.2019.04.018

Rochester IJ, Constable GA. Nitrogen-fertiliser application effects on cotton lint percentage, seed size, and seed oil and protein concentrations. Crop Pasture Sci. 2020;71:831-6. https://doi.org/10.1071/CP20288

Rosolem CA, Castoldi G, Pivetta LA, Ochsner TE. Nitrate leaching in soybean rotations without nitrogen fertilizer. Plant Soil. 2018;423:27-40. https://doi.org/10.1007/s11104-017-3494-4

Rosolem CA, Ritz K, Cantarella H, Galdos MV, Hawkesford MJ, Whalley WR, Mooney SJ. Enhanced plant rooting and crop system management for improved $\mathrm{N}$ use efficiency. Adv Agron. 2017;146:205-39. https://doi.org/10.1016/bs.agron.2017.07.002

Santos HG, Jacomine PKT, Anjos LHC, Oliveira VA, Oliveira JB, Coelho MR, Lumbreras JF, Cunha TJF. Sistema brasileiro de classificação de solos. 3. ed. rev. ampl. Rio de Janeiro: Embrapa Solos; 2013.

Shaddox TW, Kruse JK, Miller GL, Nkedi-Kizza P, Sartain JB. Surfactant-modified soil amendments reduce nitrogen and phosphorus leaching in a sand-based rootzone. J Environ Qual. 2016;45:1549-57. https://doi.org/10.2134/jeq2016.01.0025

Shareef M, Gui D, Zeng F, Waqas M, Ahmed Z, Zhang B, Iqbal H, Xue J. Nitrogen leaching, recovery efficiency, and cotton productivity assessments on desert-sandy soil under various application methods. Agric Water Manag. 2019;223:105716. https://doi.org/10.1016/j.agwat.2019.105716

Sharma V, Irmak S, Padhi J. Effects of cover crops on soil quality: Part II. Soil exchangeable bases (potassium, magnesium, sodium, and calcium), cation exchange capacity, and soil micronutrients (zinc, manganese, iron, copper, and boron). J Soil Water Conserv. 2018;73:652-68. https://doi.org/10.2489/jswc.73.6.652

Silva EC, Muraoka T, Buzetti S, Trivelin PCO. Manejo de nitrogênio no milho sob plantio direto com diferentes plantas de cobertura, em Latossolo Vermelho. Pesq Agropec Bras. 2006;41:477-86. https://doi.org/10.1590/S0100-204X2006000300015

Silva PCG, Tiritan CS, Echer FR, Cordeiro CFS, Rebonatti MD, Santos CH. No-tillage and crop rotation increase crop yields and nitrogen stocks in sandy soils under agroclimatic risk. Field Crop Res. 2020;258:107947. https://doi.org/10.1016/j.fcr.2020.107947

Soil Survey Staff. Keys to soil taxonomy. 12th ed. Washington, DC: United States Department of Agriculture, Natural Resources Conservation Service; 2014.

Subbarao GV, Nakahara K, Hurtado MDP, Ono H, Moreta DE, Salcedo AF, Yoshihashia AT, Ishikawaa T, Ishitanib M, Ohnishi-Kameyamac M, Yoshidac M, Rondonb M, Raob IM, Lascanob CE, Berryf WL, Ito O. Evidence for biological nitrification inhibition in Brachiaria pastures. Proc Natl Acad Sci. 2009;106:17302-7. https://doi.org/10.1073/pnas.0903694106

Subbarao GV, Rondon M, Ito O, Ishikawa T, Rao IM, Nakahara K, Lascano C, Berry WL. Biological nitrification inhibition (BNI) - is it a widespread phenomenon? Plant Soil. 2007;294:5-18. https://doi.org/10.1007/s11104-006-9159-3 
Sutton MA, Bleeker A, Howard CM, Erisman JW, Abrol YP, Bekunda M, Datta A, Davidson E, Vries W, Oenema O, Zhang FS. Our nutrient world. The challenge to produce more food and energy with less pollution. Edinburgh: Centre for Ecology and Hydrology; 2013.

Suzuki K, Matsunaga R, Hayashi K, Matsumoto N, Tobita S, Bationo A, Okada K. Effects of long-term application of mineral and organic fertilizers on dynamics of nitrogen pools in the sandy soil of the Sahel region, Niger. Agr Ecosyst Environ. 2017;242:76-88. https://doi.org/10.1016/j.agee.2017.03.004

Teutscherova N, Houška J, Navas M, Masaguer A, Benito M, Vazquez E. Leaching of ammonium and nitrate from Acrisol and Calcisol amended with holm oak biochar: A column study. Geoderma. 2018;323:136-45. https://doi.org/10.1016/j.geoderma.2018.03.004

Tian X, Li C, Zhang M, Li T, Lu Y, Liu L. Controlled release urea improved crop yields and mitigated nitrate leaching under cotton-garlic intercropping system in a 4-year field trial. Soil Till Res. 2018;175:158-67. https://doi.org/10.1016/j.still.2017.08.015

Wang $Y$, Ying $H$, Yin $Y$, Zheng $H$, Cui Z. Estimating soil nitrate leaching of nitrogen fertilizer from global meta-analysis. Sci Total Environ. 2019;657:96-102. https://doi.org/10.1016/j.scitotenv.2018.12.029

Yang X, Geng J, Huo X, Lei S, Lang Y, Li H, Liu Q. Effects of different nitrogen fertilizer types and rates on cotton leaf senescence, yield and soil inorganic nitrogen. Arch Agron Soil Sci. 2021;67:1507-20. https://doi.org/10.1080/03650340.2020.1799983

Yao Z, Zhang D, Liu N, Yao P, Zhao N, Li Y, Zhang S, Zhai B, Huang D, Wang Z, Cao W, Adl S, Gao Y. Dynamics and sequestration potential of soil organic carbon and total nitrogen stocks of leguminous green manure-based cropping systems on the Loess Plateau of China. Soil Till Res. 2019;191:108-16. https://doi.org/10.1016/j.still.2019.03.022

Zhang S, Shen T, Yang Y, Li YC, Wan Y, Zhang M, Tang T, Allen SC. Controlled-release urea reduced nitrogen leaching and improved nitrogen use efficiency and yield of direct-seeded rice. J Environ Manage. 2018;220:191-7. https://doi.org/10.1016/j.jenvman.2018.05.010

Zheng W, Zhang M, Liu Z, Zhou H, Lu H, Zhang W, Yang Y, Li C, Chen B. Combining controlled-release urea and normal urea to improve the nitrogen use efficiency and yield under wheat-maize double cropping system. Field Crop Res. 2016;197:52-62. https://doi.org/10.1016/j.fcr.2016.08.004 